\title{
Genetic variation, character association and evaluation of mungbean genotypes for agronomic and yield components
}

\author{
U.I.P. Perera ${ }^{1}$, K.K.J. Chandika ${ }^{1}$ and Disna Ratnasekera ${ }^{2 *}$ \\ ${ }^{1}$ Grain Legumes and Oil Crops Research and Development Centre, Angunakolapelessa. \\ ${ }^{2}$ Department of Agricultural Biology, Faculty of Agriculture, University of Ruhuna, Mapalana, Kamburupitiya.
}

Revised: 19 February 2017; Accepted: 03 May 2017

\begin{abstract}
Forty genotypes of mungbean were evaluated to compare the genetic divergence and association among agronomic and yield characteristics. Analysis of variance indicated highly significant $(\mathrm{p}<0.01)$ differences for all the traits except for 1000 seed weight. The phenotypic and genotypic coefficient of variation was the highest for grain yield per plant, followed by pod length. High broad sense heritability (> $60 \%$ ) along with high genetic advance was observed for total yield per plant, pod length, number of seeds per pod and plant height, indicating that these characteristics would be best for phenotypic selection. A significant negative correlation was observed between days to flowering and total yield per plant. Positive correlations were observed between plant height, pod length and 1000 seed weight with total yield per plant. Multivariate analysis showed that the first three principal components cumulatively accounted for $69.77 \%$ of the total variation. The present findings could be useful in selecting superior genotypes in mungbean breeding programmes.
\end{abstract}

Keywords: Genetic correlation, heritability, mungbean, principal component analysis (PCA), yield characteristics.

\section{INTRODUCTION}

Mungbean (Vigna radiata L. Wilczek) is an important annual leguminous crop mainly cultivated in the tropical, subtropical and temperate zones of Asia including Bangladesh, India, Pakistan, Myanmar, Indonesia, the Philippines, Sri Lanka, Nepal, China, Korea and Japan (Rahim et al., 2010). It is a short duration legume, hence grown solely as well as in inter and multiple cropping systems under rainfed and irrigated conditions. It increases farmer income and improves soil fertility through symbiotic nitrogen fixation (Malik, 1994). Mungbean is known to be a high source of manganese, potassium, magnesium, copper and zinc. It is rich in various B vitamins and also serves as a food filler high in protein, resistant starch and dietary fibre. In Sri Lanka, mungbean is cultivated in about 9,755 ha with an annual production of approximately 11,956 MT (DOA, 2013). The importation of mungbean in 2012 was 7,912 MT because the local production was insufficient for the requirement of the country. Hence there is a strong need for increasing the country's mungbean productivity since increasing the mungbean cultivated extent is not possible. Therefore, development of improved varieties giving high yields is necessary. In order to achieve this, selection of superior genotypes and use in breeding for genetic advancement is the most preferred procedure.

A sound knowledge on the nature and magnitude of the genetic variation of quantitative traits such as yield and its components is essentially required for developing high yielding varieties. The efficacy of selection for developing high yielding varieties depends upon the magnitude of the genetic variability of yield and yield contributing traits in the breeders' collection. It is also important to identify diverse parental combinations to create segregating progenies with maximum genetic variability for further selection (Barrett \& Kidwell, 1998). An assessment of genetic variability with the help

\footnotetext{
* Corresponding author (disnaratnasekera@gmail.com; (iD https://orcid.org/0000-0003-3176-6888)
} 
of suitable parameters such as genotypic coefficient of variation, heritability and genetic advance are absolutely necessary to start an efficient breeding programme (Mishra et al., 1995). Correlation analysis provides the information of interrelationships of important plant characters leading to a directional model for direct and/or indirect improvement in grain yield (Khan et al., 2004). Falcinelli et al. (1988) showed multivariate analyses to be a valid system to deal with germplasm collections and Dasgupta and Das (1984) stated the suitability of multivariate analysis for choosing parents for hybridisation. In order to develop mungbean varieties with a high yield potential, assessment of the genetic variation in the gene pool is of paramount importance.

Therefore, the present study was undertaken to evaluate the magnitude of genetic variation present in the mungbean germplasm based on agronomic and yield traits using multivariate techniques, and to identify the probable superior genotypes among the mungbean accessions for using as parents in future hybridisation programmes.

\section{METHODOLOGY}

\section{Plant materials}

The experiment was laid out at the research field of the Grain Legumes and Oil Crops Research and Development Centre, Angunakolapelessa during May to July in 2013. Forty mungbean accessions, which were collected from the Plant Genetic Resource Centre, Sri Lanka and from farmer fields were used in this study (Table 1). Variety MI-5 was assembled as the check line of the study. The mungbean accessions were sown in five $3 \mathrm{~m}$ length rows of each plot in a randomised complete block design maintaining the spacing between row to row and plant to plant as $30 \mathrm{~cm}$ and $15 \mathrm{~cm}$, respectively. Irrigation and weeding were undertaken as and when necessary. Crop protection and application of fertiliser were practiced according to the recommendations made by the Department of Agriculture, Sri Lanka, for mungbean cultivation as a field crop.

\section{Characterisation of mungbean germplasm}

The plants were chosen randomly from each plotexcluding the border plants and the following morphological data were recorded from each germplasm line in each replication. The traits were selected according to the descriptor for mungbean published by the International Board for Plant Genetic Resources (IBPGR, 1985), and measured based on previous studies.
1. Days to flowering - number of days taken from sowing to appearance of first flower

2. Days to $50 \%$ maturity - number of days taken from sowing to stage when $50 \%$ of the pods mature

3. Plant height at flowering $(\mathrm{cm})$ - mean height from the ground level to the tip of the raceme on the main stem at $50 \%$ flowering stage

4. Number of grains per pod - mean number of grains of ten pods taken at random from each replicate

5. Pod length $(\mathrm{cm})$ - mean length of ten mature pods taken at random

6. 1000 seed weight $(\mathrm{g})$ - weight of 100 seeds taken at random multiplied by 10

7. Total yield per plant $(\mathrm{g})$ - mean weight of the total seed yield of randomly taken 10 plants at $13 \%$ moisture content

\section{Statistical analysis}

The data were subjected to analysis of variance and all parameters, viz., mean, standard error, variance and coefficient of variation, were analysed statistically using the software package SPSS version 16. Correlation analysis was performed to determine the relationships between the characteristics. Phenotypic coefficient of variation $(\mathrm{PCV})$ and genotypic coefficient of variation (GCV) were calculated by the formulae given by Burton (1952), and heritability in broad sense $\left[\mathrm{h}^{2}(\mathrm{bs})\right]$ was calculated by the formula given by Lush (1949). Genetic advance (GA) was estimated according to the formulae by Johnson et al. (1955). The estimated $\mathrm{h}^{2}(\mathrm{bs})$ value was classified as low (below $30 \%$ ), medium $(30-60 \%)$ and high $(>60 \%)$ and genetic advance as a percent of mean $(\mathrm{GA} \%)$ was classified as low $(<10 \%)$, moderate $(10-$ $20 \%)$ and high (>20\%) as suggested by Johnson et al. (1955).

Principal component analysis (PCA) was carried out with eigen values $>1.0$ as proposed by Jeffers (1967). Both hierarchical Euclidian cluster analysis and nonhierarchical (K-means) Euclidian cluster analysis was done. The Euclidean distances were calculated by the Wards method and dendrograms were constructed to examine the relationships between the genotypes (Sokal \& Rohlf, 2003).

\section{RESULTS AND DISCUSSION}

\section{Genetic variability analysis}

The analysis of variance (Table 2) revealed significant $(p<0.01)$ differences for all the characteristics except 
for 1000 seed weight, among the accessions. It indicated that there is a genetic variability present in the studied materials suggesting that there is a possibility of improving the above traits by selection.

Table 1: Information of the 41 mungbean genotypes used in the study

\begin{tabular}{|c|c|c|c|}
\hline Code & $\begin{array}{c}\text { Gene Bank } \\
\text { accession } \\
\text { number }\end{array}$ & Origin & Place of conservation and other remarks \\
\hline MB42-1* & $\mathrm{N} / \mathrm{A}$ & Tissa, Sri Lanka & Farmer collection, early mature, green colour seeds \\
\hline MB76 & Ac 12915 & Badulla, Sri Lanka & PGRC, yellow colour seeds \\
\hline MB23 & Ac 0994 & Hambantota, Sri Lanka & PGRC, green colour seeds \\
\hline MB66 & Ac 12913 & Matale, Sri Lanka & PGRC, green colour seeds \\
\hline MB69 & Ac 12956 & Anuradhapura, Sri Lanka & PGRC, green colour seeds \\
\hline MB73 & Ac 12922 & Badulla, Sri Lanka & PGRC, green colour seeds \\
\hline MB48* & $\mathrm{N} / \mathrm{A}$ & Weeraketiya, Sri Lanka & Farmer collection, green colour large seeds \\
\hline MB80 & Ac 8310 & Hambantota, Sri Lanka & PGRC, dull green colour seeds \\
\hline MB81 & Ac 7588 & Philippines & PGRC, shiny green colour seeds \\
\hline MB82 & Ac 7472 & Philippines & PGRC, dull green colour seeds \\
\hline MB83 & Ac 7045 & Monaragala, Sri Lanka & PGRC, green colour seeds \\
\hline MB84 & Ac 7556 & Unknown & PGRC, green colour seeds \\
\hline MB85 & Ac 7316 & Philippines & PGRC, dull green colour seeds \\
\hline MB86 & Ac 7473 & Philippines & PGRC, dull green colour seeds \\
\hline MB87 & Ac 03004 & Monaragala, Sri Lanka & PGRC, green colour seeds \\
\hline MB88 & Ac 7510 & Thailand & PGRC, dull green colour seeds \\
\hline MB89 & Ac 08445 & Unknown & PGRC, green colour seeds \\
\hline MB90 & Ac 3031 & Hambantota, Sri Lanka & PGRC, yellow colour seeds \\
\hline MB91 & Ac 8432 & Unknown & PGRC, yellow colour seeds \\
\hline MB92 & Ac 2993 & Monaragala, Sri Lanka & PGRC, yellow colour seeds \\
\hline MB93 & Ac 7471 & Philippines & PGRC, dull green colour seeds \\
\hline MB94 & Ac 3032 & Hambantota, Sri Lanka & PGRC, dark green colour seeds \\
\hline MB95 & Ac 219 & Monaragala, Sri Lanka & PGRC, dull green colour seeds \\
\hline MB96 & Ac 1211 & Anuradhapura, Sri Lanka & PGRC, green colour seeds \\
\hline MB97 & Ac 8433 & Unknown & PGRC, green colour seeds \\
\hline MB98 & Ac 7474 & Philippines & PGRC, dull green colour seeds \\
\hline MB99 & Ac 8521 & Kurunegala, Sri Lanka & PGRC, green colour seeds \\
\hline MB100 & Ac 8503 & Kurunegala, Sri Lanka & PGRC, dull green colour seeds \\
\hline MB101 & Ac 7046 & Matale, Sri Lanka & PGRC, dull green colour seeds \\
\hline MB102* & N/A & Suriyaara, Sri Lanka & Farmer collection, green colour seeds \\
\hline MB103* & $\mathrm{N} / \mathrm{A}$ & Thanamalwila, Sri Lanka & Farmer collection, green colour seeds \\
\hline MB104* & $\mathrm{N} / \mathrm{A}$ & Mahawewa, Sri Lanka & Farmer collection, green colour seeds \\
\hline MB105* & $\mathrm{N} / \mathrm{A}$ & Mahawewa, Sri Lanka & Farmer collection, green colour seeds \\
\hline${\mathrm{MB} 106^{*}}^{*}$ & $\mathrm{~N} / \mathrm{A}$ & Mahawewa, Sri Lanka & Farmer collection, green colour seeds \\
\hline MB107* & $\mathrm{N} / \mathrm{A}$ & Kahakurullanpelessa, Sri Lanka & Farmer collection, green colour seeds \\
\hline MB108* & $\mathrm{N} / \mathrm{A}$ & Unknown & Farmer collection, yellow colour large seeds, long pods \\
\hline MB109* & $\mathrm{N} / \mathrm{A}$ & Unknown & Farmer collection, yellow colour large seeds, long pods \\
\hline MB110* & N/A & Unknown & Farmer collection, green colour seeds \\
\hline MB111* & $\mathrm{N} / \mathrm{A}$ & Unknown & Farmer collection, yellow colour large seeds, long pods \\
\hline MB112* & N/A & - & $\begin{array}{l}\text { Exotic \& imported Australian line available in the market, } \\
\text { commonly cultivated by farmers }\end{array}$ \\
\hline MI-5 & - & Department of Agriculture & $\begin{array}{l}\text { Used as check variety released by DOA, green colour } \\
\text { medium size seeds }\end{array}$ \\
\hline
\end{tabular}

PGRC - Plant Genetic Resources Centre, Gannoruwa

* These accessions are maintained in the respective code numbers at the Grain Legumes and Oil Crops Research and Development Centre, Angunakolapelessa 
The estimates of genotypic variance $\left(\sigma^{2} \mathrm{~g}\right)$, phenotypic variance $\left(\sigma^{2} p\right)$, genotypic coefficient of variation (GCV), phenotypic coefficient of variation (PCV), heritability $\left[\mathrm{h}^{2}(\mathrm{bs})\right]$, genetic advance in percent of mean $(\mathrm{GA} \%)$ and coefficient of variation (CV \%) for the different characteristics are presented in Table 3.

Table 2: Mean, standard error, and variance of seven yield related characteristics in 41 mungbean germplasm accessions

\begin{tabular}{lccr}
\hline Characteristic & Mean $\pm \mathrm{SE}$ & Treatment & Error \\
\hline Days to flowering & $33.46 \pm 0.57$ & $56.525^{*}$ & 9.855 \\
Days to $50 \%$ maturity & $55.63 \pm 0.25$ & $9.187^{*}$ & 1.945 \\
Plant height & $59.66 \pm 1.00$ & $206.053^{*}$ & 27.38 \\
Seeds per pod & $12.17 \pm 0.18$ & $10.973^{*}$ & 0.591 \\
Pod length & $9.55 \pm 0.26$ & $20.824^{*}$ & 1.291 \\
1000 seed weight & $52.17 \pm 1.98$ & $260.371^{\mathrm{ns}}$ & 153.165 \\
Total yield per plant & $263.34 \pm 15.68$ & $50290.294^{*}$ & 6824.061 \\
\hline
\end{tabular}

* Significant at $1 \%$ level of significance ns - not significant

Table 3: Estimates of genetic components of seven yield related characteristics in 41 mungbean germplasm accessions

\begin{tabular}{lrrrrrr}
\hline Characteristic & GCV \% & PCV \% & $\mathrm{h}^{2}(\mathrm{bs})$ & GA & GA \% & CV \% \\
\hline & 11.79 & 15.07 & 61.22 & 6.36 & 19.00 & 10.92 \\
Days to flowering & 2.79 & 3.75 & 55.38 & 2.38 & 4.28 & 2.83 \\
Days to 50 \% maturity & 12.94 & 15.63 & 68.51 & 13.16 & 22.06 & 10.70 \\
Plant height & 15.29 & 16.54 & 85.41 & 3.54 & 29.10 & 9.61 \\
Seeds per pod & 26.72 & 29.25 & 83.45 & 4.80 & 50.28 & 17.38 \\
Pod length & 11.46 & 26.34 & 18.92 & 5.36 & 10.27 & 24.34 \\
1000 seed weight & 45.71 & 55.44 & 67.98 & 204.45 & 77.64 & 38.13 \\
Total yield per plant & & & & & & \\
\hline
\end{tabular}

GCV - genotypic coefficient of variation; PCV - phenotypic coefficient of variation; $\mathrm{h}^{2}(\mathrm{bs})$ - heritability; $\mathrm{GA}=$ genetic advance; $\mathrm{GA} \%=$ genetic advance in percent of mean; $\mathrm{CV}=$ coefficient of variation

The $\mathrm{CV}$ indicated that there were significant differences among the genotypes for the measured characteristics. The maximum $\mathrm{CV}$ was found in total yield per plant followed by 1000 seed weight and pod length. The PCV was slightly higher than the GCV for all the characteristics; hence small differences between PCV and GCV signifying the incidence of high genetic variability for the genotypes and less influence of the environment for the expression of tested characteristics. These results are in agreement with previously reported research indicating comparable effects of the environment (Siddique et al., 2006; Makeen et al., 2007). Comparatively higher values of GCV and PCV were found for total yield per plant, pod length, 1000 seed weight, and seeds per pod. The highest GCV was found for total yield per plant followed by the pod length and number of seeds per pod, indicating high genetic variability for these characteristics. A greater value of broad sense heritability (more than $60 \%$ ) was found for all the observed characteristics except for 1000 seed weight, which was recorded as low heritability, and days to $50 \%$ maturity, that showed a moderate value. These highly heritable traits are expected to remain stable under different environments, as the environment is less influential and could easily be improved through selection pressure. The low heritability value observed in 1000 seed weight indicates the influence of the environment, so that direct selection for the trait would be unsuccessful. The heritability estimates in broad sense along with genetic advance would be more reliable when selecting the best individuals (Ramanujam \& Thirumalachar, 1967). High 
heritability associated with high genetic advance was observed for total yield per plant, pod length, number of seeds per pod and plant height, suggesting that these characteristics are controlled by additive genetic effect to a great amount and improvement of these characters would be effective through phenotypic selection. Similar results were reported by previous studies for plant height and number of pods per plant (Vikas \& Singh, 1998), and seed yield per plant (Sharma, 1999). Moreover, the high heritability and genetic advance associated to these traits is an indication that they can effectively be transferred to subsequent generations.

Table 4: Correlation coefficients between seven yield related characteristics in 41 mungbean germplasm accessions

\begin{tabular}{lccccccc}
\hline${ }^{* *}$ Characteristic & DF & DM & PH & S/P & PL & SW & TY/P \\
\hline DF & 1 & & & & & & \\
DM & 0.308 & 1 & & & & & \\
PH & 0.124 & 0.034 & 1 & & & & \\
S/P & 0.078 & 0.03 & $0.44^{*}$ & 1 & & & \\
PL & -0.02 & -0.289 & $0.313^{*}$ & $0.619^{*}$ & 1 & & \\
SW & 0.008 & $-0.305^{*}$ & -0.01 & 0.103 & 0.313 & 1 & \\
TY/P & $-0.407^{*}$ & -0.244 & 0.114 & -0.059 & 0.153 & 0.155 & 1 \\
\hline
\end{tabular}

* Significant at $5 \%$ level

${ }^{* *} \mathrm{DF}$ - days to flowering; DM - days to $50 \%$ maturity; PH - plant height; $\mathrm{S} / \mathrm{P}$ - number of seeds per pod; PL - pod length; SW - 1000 seed weight; TY/P - total yield per plant

\section{Character association}

\section{Correlation coefficient analysis}

Correlation coefficient analysis among the grain yield and its contributing characteristics are shown in Table 4. The simple correlation coefficient for total yield per plant showed a positive correlation with plant height, pod length and 1000 seed weight, whereas it was negatively correlated with days to flowering, days to $50 \%$ maturity and number of seeds per pod. Days to flowering was positively associated with days to $50 \%$ maturity, plant height and number of seeds per pod and 1000 seed weight. The number of seeds per pod was positively and significantly $(\mathrm{p}<0.05)$ correlated with the pod length while 1000 seed weight was positively correlated with days to flowering, seeds per pod and pod length. Although significant correlations were observed, none of them showed strong correlations between the characteristics under study. A negative correlation between plant height and 1000 seed weight was reported by a previous research (Rahman et al., 2002).

\section{Principal component analysis}

The first three principal components with eigen values $>1$ contributed to $69.8 \%$ of the variability
Table 5: Eigen values and percentage total variation explained by each component and loading variables as revealed by the principal components analysis (PCA) of seven yield related characteristics in 41 mungbean germplasm accessions

\begin{tabular}{lccr}
\hline & PC1 & PC2 & PC3 \\
\hline Eigen value & 2.096 & 1.72 & 1.068 \\
Percentage of variance & 27.079 & 21.952 & 20.738 \\
Cumulative percentage & 27.079 & 49.031 & 69.769 \\
& & & \\
Variable & Eigen vector & & \\
Days to flowering & 0.114 & 0.831 & -0.031 \\
Days to 50\% maturity & 0.032 & 0.424 & -0.662 \\
Plant height & 0.778 & -0.065 & -0.205 \\
Seeds per pod & 0.857 & 0.124 & 0.099 \\
Pod length & 0.726 & -0.075 & 0.483 \\
1000 seed weight & 0.058 & 0.06 & 0.847 \\
Total yield & 0.107 & -0.799 & 0.096 \\
\hline
\end{tabular}

amongst genotypes evaluated for seven quantitative traits (Table 5). The characteristics contributing more positively to PC1 were plant height, seeds per pod and pod length, whereas days to flowering and total yield per plant contributed for PC2. PC3 was more related to days to maturity and 1000 seed weight. 
A two-dimensional scatter diagram was constructed using component I as the X-axis and component III as the Y-axis, reflecting in the relative position (Figure 1). As per the scatter diagram the genotypes were apparently distributed into five clusters. It reveals that the genotypes of cluster I and cluster $\mathrm{V}$ were more diverse from the genotypes of cluster II, III and IV. It is expected that the maximum amount of heterosis is exhibited in hybridisation of the genotypes in the most divergent clusters. In the present study, the maximum distance was observed between cluster I and III. Considering the yield characteristics and early maturity, promising genotypes can be selected from cluster I for further evaluation, and crosses comprising cluster I and V will perform high heterosis.

Cluster means for different quantitative traits for each cluster are presented in Table 6 where 41 mungbean genotypes are grouped into five clusters through hierarchical cluster analysis. Kumar et al. (2009) grouped 60 genotypes into 13 clusters and Sandhu and Brar (2002) grouped 39 mutants of mungbean into eight clusters based on the divergence among mungbean genotypes. The mungbean genotypes in cluster I were the tallest while cluster $\mathrm{V}$ represented the shortest. Cluster II contained the maximum number of genotypes (23) followed by cluster III (6) and cluster IV (6) and the lowest number of genotypes was contained in cluster I (3) and cluster V (3). The genotypes in cluster I have recorded the highest number of seeds per pod, long pods and the highest yield per plant. The separation of clusters I, III, IV and V from cluster II occurred mainly on the basis of days to flowering. The genotypes in cluster II composed of the least number of days to flowering and early maturity, where MI-5, the check variety used in the study was also grouped. Cluster III was characterised by shorter pods, lowest 1000 seed weight and maximum days to maturity. Cluster $\mathrm{V}$ showed the shortest plant stature with the least number of seeds per pod and higher 1000 seed weight, while cluster IV recorded the lowest

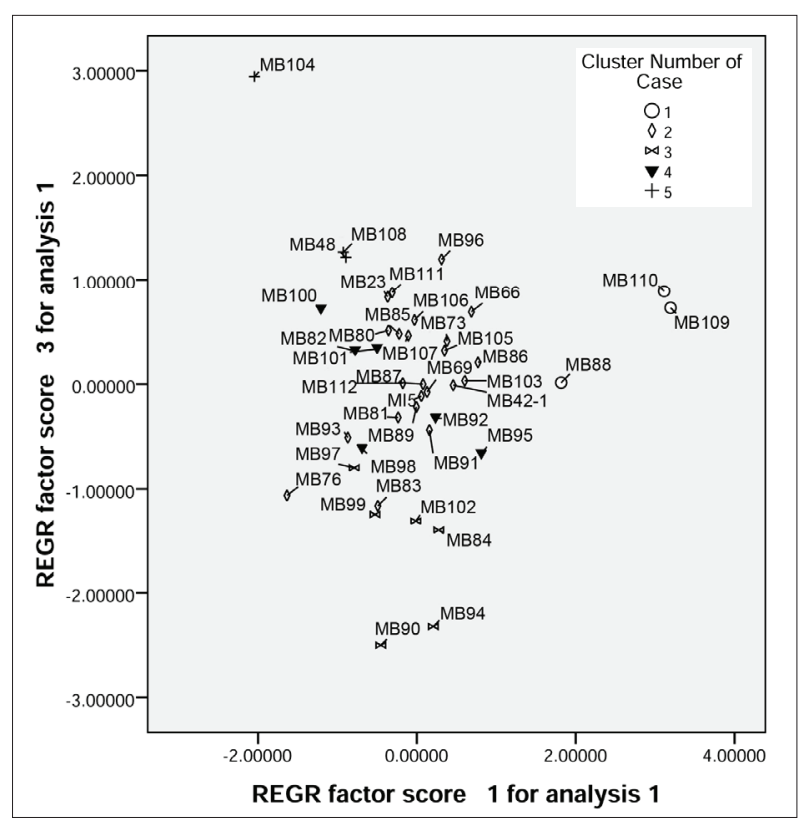

Figure 1: Scatter plot of morphological variation in 41 genotypes of mungbean based on mean values obtained from the first and third components of principal components analysis.

Table 6: Means for five clusters for each of seven quantitative traits in 41 mungbean genotypes

\begin{tabular}{lccccc}
\hline${ }^{*}$ Characteristic & 1 & 2 & 3 & 4 & 5 \\
\hline DF & 33.33 & 32.04 & 33.83 & 38.5 & 33.67 \\
DM & 55 & 55.26 & 57.5 & 56.67 & 53.33 \\
PH & 70.67 & 59.74 & 60.5 & 56.83 & 52 \\
S/P & 14.93 & 12.17 & 11.7 & 12.15 & 10.37 \\
PL & 13.77 & 9.41 & 8.3 & 8.83 & 10.32 \\
SW & 57.07 & 54.41 & 34.02 & 52.18 & 66.43 \\
TY/P & 334.27 & 306.18 & 192.62 & 129.14 & 273.83 \\
\hline
\end{tabular}

* DF - days to flowering; DM - days to $50 \%$ maturity; $\mathrm{PH}$ - plant height; S/P - number of seeds per pod; PL - pod length; SW - 1000 seed weight; TY/P - total yield per plant

Table 7: Composition of clusters for 41 mungbean genotypes

\begin{tabular}{ccl}
\hline Cluster & $\begin{array}{c}\text { No. of } \\
\text { genotypes }\end{array}$ & Genotype \\
\hline & 3 & MB 88, MB 109, MB 110 \\
1 & 23 & MB 42-1, MB 76, MB 23, MB 66, MB 69, MB 73, MB 80, MB 82, MB 83, \\
2 & & MB 85, MB 86, MB 89, MB 91, MB 93, MB 96, MB 97, MB 103, MB 105, \\
& 6 & MB 106, MB 107, MB 111, MB 112, MI 5, \\
3 & 6 & MB 81, MB 87, MB 92, MB 95, MB 100, MB 101 \\
4 & 3 & MB 48, MB 104, MB 108 \\
\hline
\end{tabular}


yield per plant. The number of genotypes in each cluster with the genotype name is presented in Table 7 .

\section{CONCLUSION}

The genotypes as a whole showed considerable genetic variability to be exploited in breeding mungbean for the development of high yielding varieties with several other useful agronomic traits. The study reveals that plant height, number of seeds per pod, pod length and total yield per plant provide promising selection criteria, as they possess high values of heritability and genetic advance. Therefore, emphasis should be placed on these characteristics for formulating reliable selection indices for the development of promising mungbean varieties.

\section{Acknowledgement}

The authors would like to thank the Plant Genetic Resources Centre, Department of Agriculture, Sri Lanka for providing the seed materials for the study.

\section{REFERENCES}

1. Barrett B.A. \& Kidwell K.K. (1998). AFLP-based genetic diversity assessment among wheat cultivars from the Pacific Northwest. Crop Science 38: 1261 - 1271.

2. Burton G.W. (1952). Quantitative inheritance in grasses. Proceedings of the $6^{\text {th }}$ International Grassland Congress, volume 1, Pennsylvania State College, 17 - 23 August. pp. $277-283$.

3. Dasgupta T. \& Das P.K. (1984). Multivariate analysis and selection of parents for hybridization in blackgram. Philippine Agriculturist 57(1): 86 - 92.

4. Department of Agriculture (DOA) (2013). Agstat Pocket Book of Agricultural Statistics, Volume 10, pp. 21. Department of Agriculture, Sri Lanka.

5. Falcinelli M., Veronesi F. \& Lorenzetti S. (1988). Evaluation of an Italian germplasm collection of Lolium perenne L., through a multivariate approach. Proceedings of the Eucarpia Fodder Crops Section Meeting, Lusignan, France, pp. $22-24$.

6. International Board for Plant Genetic Resources (IBPGR) (1985). Descriptors for Vigna mungo and $V$. radiata (Revised). International Board for Plant Genetic Resources, Rome, Italy. pp. $11-15$.

7. Jeffers J.N.R. (1967). Two case studies in the application of principal component analysis. Applied Statistics 16: $225-236$.

DOI: https://doi.org/10.2307/2985919

8. Johnson H.W., Robinson H.F. \& Comstock R.E. (1955).
Estimates of genetic and environmental variability in soybean. Agronomy Journal 47: 314 - 318.

9. Lush J.L. (1949). Heritability of quantitative characters in farm animals. Proceedings of the $8^{\text {th }}$ International Genetic Congress, Stockholm, Sweden, 7 - 14 July. pp. $356-$ 357.

DOI: https://doi.org/10.1111/j.1601-5223.1949.tb03347.x

10. Makeen K., Garard A., Arif J. \& Archana K.S. (2007). Genetic variability and correlation studies on yield and its components in mungbean [Vigna radiata (L). Wilczek]. Journal of Agronomy 6: 216 - 218.

DOI: https://doi.org/10.3923/ja.2007.216.218

11. Malik B.A. (1994). Grain legumes. Crop Production (ed. M.S. Nazir), p. 301. National Book Foundation, Islamabad, Pakistan.

12. Mishra A.K., Yadav L.N. \& Raghu J.S. (1995). Variability of metric traits and character association in Vigna radiata. Agricultural Science Digest (Karnal) 15: 51 - 54.

13. Khan M.D., Khalil I.H., Khan M.A. \& Ikramullah (2004). Genetic divergence and association for yield and related traits in mash bean. Sarhad Journal of Agriculture 20: 555 -561 .

14. Kumar R., Singh S.P. \& Tripathi M.K. (2009). Nature of genetic diversity across generations in mungbean (Vigna Radiata L. Wilczek). The IUP Journal of Life Sciences 3: $35-40$.

15. Rahim M.A., Mia A.A., Mahmud F., Zeba N. \& Afrin K.S. (2010). Genetic variability, character association and genetic divergence in mungbean (Vigna radiata $\mathrm{L}$. Wilczek). Plant Omics Journal 3(1): 1 - 6 .

16. Rahman A.K.M., Nag B.L., Uddin M.S. \& Miah M.A. (2002). Correlation and path analysis of seed yield in mungbean. Bangladesh Journal of Agriculture Research 27: $305-308$.

17. Ramanujam S. \& Thirumalachar D.K. (1967). Genetic variability of certain characters in red pepper (Capsicum annum). Mysore Journal of Agriculture Science 1: 30 - 36.

18. Sandhu J.S. \& Brar W.S. (2002). Genetic divergence in some mutants of mungbean (Vigna radiata L. Wilczek). Journal of Research 39: 161 - 164.

19. Sharma R.N. (1999). Heritability and character association in non-segregating populations of mungbean (Vigna radiata L. Wilczek). Journal of Inter Academicia 3: 5-10.

20. Siddique M., Faisal M., Anwar M. \& Shahid I.A. (2006). Genetic divergence, association and performance evaluation of different genotypes of mungbean (Vigna radiata). International Journal of Agricultural Biology 6 : $793-795$.

21. Sokal R.R. \& Rohlf T.J. (2003). Biometry: the Principles and Practice of Statistics in Biological Research. $8^{\text {th }}$ printing. WH Freeman, San Francisco, USA.

22. Vikas V.R.S.P. \& Singh S.P. (1998). Genetic variability in mungbean (Vigna radiata L. Wilczek) over environments in kharif season. Annals of Agriculture Biology Research 3: $211-215$. 